\title{
Structural Changes and Their Implications in Foamed Flexible Polyurethane Composites Filled with Rapeseed Oil-Treated Ground Tire Rubber
}

\author{
Paulina Kosmela, Adam Olszewski, Łukasz Zedler (D), Paulina Burger, Krzysztof Formela (1) \\ and Aleksander Hejna * ${ }^{\mathbb{C}}$
}

check for updates

Citation: Kosmela, P.; Olszewski, A.; Zedler, Ł.; Burger, P.; Formela, K.; Hejna, A. Structural Changes and Their Implications in Foamed Flexible Polyurethane Composites Filled with Rapeseed Oil-Treated Ground Tire Rubber. J. Compos. Sci. 2021, 5, 90. https://doi.org/10.3390/jcs5030090

Academic Editors:

Francesco Tornabene and

Farshid Pahlevani

Received: 24 February 2021

Accepted: 19 March 2021

Published: 23 March 2021

Publisher's Note: MDPI stays neutral with regard to jurisdictional claims in published maps and institutional affiliations.

Copyright: (c) 2021 by the authors. Licensee MDPI, Basel, Switzerland. This article is an open access article distributed under the terms and conditions of the Creative Commons Attribution (CC BY) license (https:/ / creativecommons.org/licenses/by/ $4.0 /)$.
Department of Polymer Technology, Gdańsk University of Technology, Narutowicza 11/12, 80-233 Gdańsk, Poland; paulina.kosmela@pg.edu.pl (P.K.); adam.olszewski@student.pg.edu.pl (A.O.); lukasz.zedler@pg.edu.pl (Ł.Z.); paulina_anna_burger@interia.pl (P.B.); krzform1@pg.edu.pl (K.F.)

* Correspondence: aleksander.hejna@pg.edu.pl

\begin{abstract}
The utilization of post-consumer car tires is an essential issue from an ecological and economic point of view. One of the simplest and the least harmful methods is their material recycling resulting in ground tire rubber (GTR), which can be further applied as fillers for polymer-based composites. Nevertheless, insufficient interfacial interactions implicate the necessity of GTR modification before introduction into polymer matrices. In this study, we investigated the influence of rapeseed oil-assisted thermo-mechanical treatment of GTR using a reactive extrusion process on the processing, structure, and performance of flexible polyurethane/GTR composite foams. Applied modifications affected the processing of polyurethane systems. They caused a noticeable reduction in the average cell size of foams, which was attributed to the potential nucleating activity of solid particles and changes in surface tension caused by the presence of oil. Such an effect was especially pronounced for the waste rapeseed oil, which resulted in the highest content of closed cells. Structural changes caused by GTR modification implicated the enhancement of foams' strength. Mechanical performance was significantly affected by the applied modifications due to the changes in glass transition temperature. Moreover, the incorporation of waste GTR particles into the polyurethane matrix noticeably improved its thermal stability.
\end{abstract}

Keywords: polyurethane foams; ground tire rubber; composites; oil modification; recycling

\section{Introduction}

Ground tire rubber (GTR) is a waste material generated currently in enormous amounts during material recycling of post-consumer car tires. At present, literature works analyzed the application of GTR in the manufacturing of acoustic insulation [1], damping layers [2], asphalts [3], highway embankments [4], or concretes [5]. Moreover, this material can be applied in steelmaking. The GTR can be used as a partial or complete substitute for coke, which has been proven to lead to a more stable slag [6]. Furthermore, the introduction of ELT significantly increases the reduction and carburization of the metal produced compared to coke alone. The researchers conclude that hydrogen is introduced by rubber-based waste. Thus, this element's reactions promote faster coal gasification (faster reduction of iron oxide in coke) [7]. Ground tire rubber can also be applied as fuel during heat generation because of the relatively high calorific value (33-35 MJ/kg). Nevertheless, such solutions are characterized by few disadvantages. First of all, it is necessary to design and build the proper plant, guaranteeing an efficient reduction in harmful emissions. Combustion of GTR results in the generation of significant amounts of dioxins, furans, styrene, and other compounds, which can show carcinogenic effects [8]. Moreover, according to Amari et al. [9], the combustion of car tires enables the recovery of only $37 \%$ of the energy required to produce a tire (including the production of raw 
materials and the tire itself, as well as the grinding of tires to the required size for use as fuel).

Therefore, due to the above-mentioned disadvantages and the fact that these applications still do not guarantee sufficient demand for recycled rubber waste, much research is currently being conducted to find potential applications for GTR, among others in the plastics industry [10]. The production of composite materials seems to be the most promising research direction due to the multitude of polymer-rubber products' potential applications. So far, GTR has been used as a filler in composites based on polyurethanes, polyolefins, or rubber [11,12]. However, the authors point out the main problem limiting the broader use of waste rubber in producing polymer composites: low compatibility of the GTR with polymer matrices [13]. As a result, the mechanical properties of the obtained composites are insufficient for potential applications. The solution to this problem is modifying waste rubber, consisting of surface oxidation, partial devulcanization, or grafting various chemical compounds onto its surface [14]. This kind of modification makes it possible to give new functional properties to waste rubber. The literature describes many modification methods of GTR, including mechanical, thermo-mechanical, mechanical-chemical, and other methods such as microwave, ultrasound, microorganisms, or supercritical $\mathrm{CO}_{2}$ [15]. Nevertheless, the vast majority of the methods described are based on processes of a periodic character. This causes the presented methods to have several disadvantages, among which we should include the following:

- The use of organic and inorganic solvents-as a result, the product usually requires additional purification, which complicates the process (additional unit operations), generates significant amounts of wastewater, and increases the processing time. Moreover, for many years, it has been suggested that the technology should use as few solvents as possible, as their use is not necessary [16].

- The need to start and stop production every day and sometimes more frequently affects the efficiency of the process and its economic aspect.

- The use of microwave and plasma reactors is costly and often does not ensure very high process efficiency [16].

These disadvantages effectively limit the industrial application of the above-mentioned periodic methods. Therefore, it is reasonable to search for methods of GTR modification of continuous character. A potentially very effective method is the in situ modification of fillers in the reactive extrusion process. This process is fast, relatively cheap, and considered to be an environmentally friendly alternative to traditional batch methods of GTR modification [17]. The use of reactive extrusion allows for exact adjustment of the modification of the conditions by changing process parameters such as temperature on particular zones of the barrel, screw rotational speed, throughput, residence time of the material in the extruder, or, finally, the magnitude of shear forces acting on the material regulated by changing the screw configuration $[18,19]$. An advantage of this process is the lack of need to use solvents (although this method does not preclude their use), eliminating additional purification processes. These factors lead to the continued development and increased interest in this method [20]. Even though reactive extrusion is a process that has been known for many years, its application to the modification of rubber GTR is a relatively new direction of research. As mentioned above, an appropriately modified rubber with a structure that would ensure strong enough interactions at the matrix-filler interface could be successfully used to produce polymer-GTR composites.

An attractive candidate for the matrix is polyurethane foams. They are an extensive group of materials, which can be most simply divided into rigid and flexible foams [21]. The first group includes foams used mainly as thermal insulating materials. The most important thing in their case is obtaining a cellular structure that ensures the lowest possible thermal conductivity coefficient [22]. The introduction of GTR into rigid polyurethane foams could positively influence the insulating properties of the final product due to the lower thermal conductivity coefficient of rubber compared to solid polyurethane $(\approx 160$ and $\approx 220 \mathrm{~mW} /(\mathrm{m} \cdot \mathrm{K})[23]$. 
Nevertheless, to achieve this effect, appropriate adjustment of the cellular structure is required, and so far, there are no reports of this type in the literature. Therefore, in terms of GTR application, flexible polyurethane foams seem to be more prospective, mainly due to their multitude of applications. These materials are commonly used in furniture, automotive, construction, or packaging industries [24]. They are used in products where the material cost is often an essential aspect. Using relatively cheap GTR could lower the material's cost and significantly increase its attractiveness to potential buyers. The literature data indicate that the introduction of GTR into flexible polyurethane foams has a beneficial effect on improving damping properties both in the direction of mechanical and acoustic vibrations [25].

In our previous work [26], we noted the increase in mechanical strength and an improvement in the material's thermal stability with the addition of GTR. In another paper [27], we reported that the partial oxidation of rubber surface might enhance the potential interactions with polyurethane matrix due to the increase in the GTR hydroxyl value measured by the titration-based method [28]. Depending on the level of modification, the mechanical properties of the resulting foams may be noticeably improved. The authors of other works indicated similar observations. Cachaço et al. [29] observed a significant increase in compressive strength and modulus of elasticity due to the introduction of GTR into the foamed flexible polyurethane matrix. Gayathri et al. [30] reported an increase in tensile and compression with the addition of GTR. They also indicate a significant increase in the sound absorption coefficient of the material, which is a great advantage from the point of view of using foams as damping materials. A similar effect related to sound absorption was observed by Zhang et al. [31]. Moreover, they studied the effect of the addition of unmodified and partially devulcanized GTR on the structure and properties of the material. They observed that devulcanization allowed decreasing the pore size in the foam, which should be considered beneficial from the point of view of mechanical properties. Moreover, the introduction of rubber dust into the foam allowed increasing the loss modulus.

Therefore, in the presented paper, we investigated another GTR modification method to enhance the performance of polyurethane/GTR composites. The influence of oil-assisted thermo-mechanical treatment of ground tire rubber in a twin-screw extruder and the impact of oil type (fresh or waste rapeseed oil) and content (20 or 40 parts per hundred rubber) on the processing, structure, and performance of composites based on a foamed flexible polyurethane matrix was investigated. The application of oil as a modifier of GTR may enable its swelling and, according to the literature data, it may improve the heat transfer in rubber during thermo-mechanical treatment [32]. Moreover, the oil may act as a processing aid, and by the decrease, the screws' torque reduces the amount of mechanical energy required for GTR processing [33]. The goal of the work was to apply the waste rapeseed oil generated by food companies and restaurants. It would result in the utilization of waste rubber and waste oil simultaneously in one solution, based on the continuous process. For better understanding, the raw rapeseed oil was also applied for comparison.

\section{Materials and Methods}

\subsection{Materials}

The applied ground tire rubber was provided by Recykl S.A. (Śrem, Poland). It was produced by the ambient grinding of post-consumer tires (from passenger cars and trucks in 50:50 mass ratio). The average particle size of applied GTR is around $0.6 \mathrm{~mm}$.

Ground tire rubber was modified with two types of rapeseed oil, the fresh one (FO) was acquired from Lidl (Gdańsk, Poland), and waste (WO) was obtained from a local restaurant (Gdańsk, Poland). The main fatty acids present in the rapeseed oil are presented in Figure 1. It can be seen that the fatty acids present in the rapeseed oil as glycerol esters do not contain hydroxyl groups in their structure, contrary for example to castor oil [34]. Nevertheless, due to the presence of unsaturated bonds, they are prone to oxidation during 
themo-mechanical treatment of the GTR/oil mixture, which may result in the generation of hydroxyls.

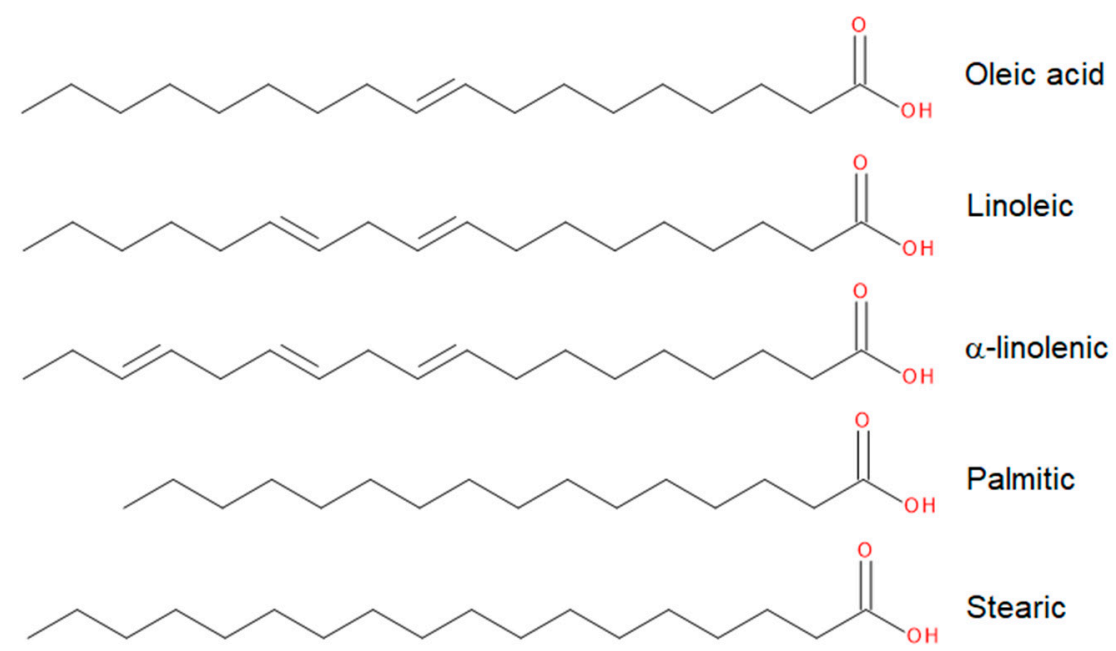

Figure 1. The main fatty acids present in rapeseed oil.

Polyurethanes were synthesized from a Rokopol ${ }^{\circledR}$ F3000 and Rokopol ${ }^{\circledR}$ V700 polyols obtained from the PCC Group (Brzeg Dolny, Poland), with the addition of glycerol acquired from Sigma Aldrich (Poznan, Poland). The polymeric methylenediphenyl-4, $4^{\prime}-$ diisocyanate (pMDI) SPECFLEX NF 434, acquired from M. B. Market Ltd. (Baniocha, Poland) was used as an isocyanate component. The solution of potassium acetate PC CAT ${ }^{\circledR}$ TKA30 from Performance Chemicals (Belvedere, UK), 33 wt \% solution of 1,4-diazabicyclo [2.2.2] octane in dipropylene glycol (Dabco33LV from Air Products (Allentown, PA, USA)), and dibutyltin dilaurate (DBTDL) from Sigma Aldrich (Poznań, Poland) were applied as catalysts. Distilled water was used as a chemical blowing agent.

For the evaluation of the chemical structure of modified GTR, the following chemicals were applied: acetone, dibutylamine, chlorobenzene, hydrochloric acid, toluene diisocyanate (TDI), and $3^{\prime}, 3^{\prime \prime}, 5^{\prime}, 5^{\prime \prime}$-tetrabromophenolsulfonphthalein. All chemicals were acquired from Sigma Aldrich (Poznań, Poland) and were used as received.

\subsection{Modifications of Ground Tire Rubber}

Applied modifications of ground tire rubber were described in our previous work [33]. Briefly, treatment of GTR was performed with an EHP $2 \times 20$ Sline co-rotating twin-screw extruder from Zamak Mercator (Skawina, Poland) with a screw diameter of $20 \mathrm{~mm}$ and an L/d ratio of 40 . Before the modification, GTR was premixed with 20 or 40 phr (parts per hundred of rubber) of selected oil. Then, it was dosed into the extruder hopper with a constant throughput of $2 \mathrm{~kg} / \mathrm{h}$. The barrel temperature in all zones was set at $200{ }^{\circ} \mathrm{C}$. The screw speed was set at $350 \mathrm{rpm}$. For each set of parameters, extrusion was carried out for at least 5 min after stabilizing the extruder's motor load, indicating the stabilization process. For comparison, GTR without oil addition was also processed. GTR refers to the unmodified GTR, while GTR $\mathrm{TM}_{\mathrm{TM}}$ refers to the one thermo-mechanically treated without oil addition in the following sections. Simultaneously, modified samples were named GTR $\mathrm{XY}_{\mathrm{Y}}$ where $X$ indicates the modifier's content (20 or 40 phr) and $Y$ indicates its type (fresh oil or waste oil). In Table 1, there are presented hydroxyl values of modified ground tire rubber, which are determined according to the methodology presented in our previous works $[28,33,35]$. The impact of GTR treatment on its performance was also described in these works $[28,33,35]$. Changes in the hydroxyl numbers were attributed to the partial oxidation of GTR/oil mixtures and generation of hydroxyl, formyl, and carbonyl groups, as reported in previous works [36,37]. 
Table 1. Measured hydroxyl values of applied ground tire rubber (GTR) samples.

\begin{tabular}{ccccccc}
\hline GTR Type & GTR & GTR $_{\text {TM }}$ & GTR $_{\text {20FO }}$ & GTR $_{\text {40FO }}$ & GTR $_{\text {20wO }}$ & GTR $_{\text {40wO }}$ \\
\hline $\begin{array}{c}\text { Hydroxyl number, } \\
\text { mg KOH/g }\end{array}$ & $61.7 \pm 3.0$ & $37.8 \pm 1.3$ & $56.9 \pm 2.4$ & $53.1 \pm 1.0$ & $75.2 \pm 3.5$ & $75.9 \pm 0.9$ \\
\hline
\end{tabular}

\subsection{Preparation of Polyurethane/Ground Tire Rubber Composite Foams}

Composite foams were prepared on a laboratory scale by a single-step method with the ratio of isocyanate to hydroxyl groups of 1:1. The content of modified ground tire rubber in composite foams was fixed at $20 \mathrm{wt} \%$. Before polymerization, filler was mixed with the polyol components at $1000 \mathrm{rpm}$ for $60 \mathrm{~s}$ to enhance its distribution in the final material. All components were mixed for $10 \mathrm{~s}$ at $1800 \mathrm{rpm}$ and poured into a closed aluminum mold with dimensions of $20 \times 10 \times 4 \mathrm{~cm}^{3}$. After demolding, the samples were conditioned at room temperature for $24 \mathrm{~h}$. The amount of reaction mixture poured into the mold was adjusted to obtain foams with a similar level of apparent density, which noticeably affects cellular materials' performance. As a result, all foams were characterized by an apparent density of $205 \pm 6 \mathrm{~kg} / \mathrm{m}^{3}$.

Table 2 contains the details of foam formulations. In the following sections, the neat foam without the addition of GTR was named PU, while composite foams were named PU/X, where $X$ indicates the type of introduced GTR. The hydroxyl numbers of modified GTR were not included in the calculations during formulation development. Such an approach was taken to investigate the changes in foams' performance caused by incorporating GTR with functional groups able to interact with the polyurethane matrix.

Table 2. Formulations of prepared polyurethane foams.

\begin{tabular}{ccc}
\hline \multirow{2}{*}{ Component } & Neat Foam & \multicolumn{2}{c}{ Composite Foams } \\
\cline { 2 - 3 } & \multicolumn{2}{c}{ Content, wt \% } \\
\hline F3000 & 32.6 & 26.1 \\
V700 & 32.6 & 26.1 \\
Glycerol & 0.8 & 0.6 \\
DBTDL & 0.6 & 0.5 \\
33LV & 0.4 & 0.3 \\
TKA30 & 0.4 & 0.3 \\
Water & 0.3 & 0.3 \\
pMDI & 32.3 & 25.8 \\
GTR/modified GTR & - & 20.0 \\
\hline
\end{tabular}

\subsection{Measurements}

For all the samples, the rise time (time of volumetric expansion) was determined. Moreover, during polymerization, the temperature inside the foam surface was measured with a thermocouple.

After conditioning, foamed polyurethane composites were cut into samples whose properties were later determined following the standard procedures.

The samples' morphology was evaluated using a Bresser LDC $50 \times-2000 \times$ optical microscope (Rhede, Germany). Based on the obtained images, the average cell size was determined. At least 100 cells for each sample were taken into account during analysis.

The content of open cells in foamed PU/GTR composites was determined using an Ultrapyc 5000 Foam gas pycnometer from Anton Paar (Graz, Austria) according to ASTM D6226 standard. The following measurement settings were applied: gas-helium; target pressure - $3.0 \mathrm{psi}$; foam mode—on; measurement type — corrected; flow direction—sample first; temperature control—on; target temperature- $20.0^{\circ} \mathrm{C}$; flow mode-monolith; cell size-medium, $45 \mathrm{~cm}^{3}$; preparation mode-flow; time of the gas flow- $0.5 \mathrm{~min}$. Ten runs were performed for each sample. 
The sol fraction content was determined as the mass difference of prepared foams before swelling in xylene $\left(\mathrm{W}_{1}\right)$ and after extraction $\left(\mathrm{W}_{2}\right)$, according to the following Formula (1):

$$
\text { Sol fraction content }=\left(\mathrm{W}_{1}-\mathrm{W}_{2}\right) / \mathrm{W}_{1} \cdot 100 \% .
$$

Three samples were analyzed for each foam.

The compressive strength of studied samples was estimated following ISO 604. The cylindric samples with dimensions of $20 \times 20 \mathrm{~mm}^{2}$ (height and diameter) were measured with a slide caliper with an accuracy of $0.1 \mathrm{~mm}$. The compression test was performed on a Zwick/Roell Z020 tensile tester (Ulm, Germany) at a constant speed of 15\%/min until reaching $60 \%$ deformation. Five samples were tested for each foam.

The tensile strength of microporous polyurethane elastomers was estimated following ISO 1798. The beam-shaped samples with dimensions of $10 \times 10 \times 100 \mathrm{~mm}^{3}$ were measured with a slide caliper with an accuracy of $0.1 \mathrm{~mm}$. The tensile test was performed on a Zwick/Roell tensile tester (Ulm, Germany) at a constant speed of $500 \mathrm{~mm} / \mathrm{min}$. Five samples were tested for each foam.

Dynamical mechanical analysis (DMA) was performed using a Q800 DMA instrument from TA Instruments (New Castle, USA) at a heating rate of $4{ }^{\circ} \mathrm{C} / \mathrm{min}$ and the temperature range from -100 to $150{ }^{\circ} \mathrm{C}$. Samples were cylindrical-shaped, with dimensions of $10 \times 12 \mathrm{~mm}^{2}$. Measurements were performed in the single cantilever bending mode with a frequency of $1 \mathrm{~Hz}$.

The thermogravimetric (TGA) analysis of GTR and composites was performed using the TG 209 F3 apparatus from Netzsch (Selb, Germany). Samples of composites weighing approximately $10 \mathrm{mg}$ were placed in a ceramic dish. The study was conducted in an inert gas atmosphere-nitrogen in the range from 30 to $900{ }^{\circ} \mathrm{C}$ with a temperature increase rate of $10^{\circ} \mathrm{C} / \mathrm{min}$.

\section{Results and Discussion}

Figure 2 presents the temperature changes inside the foam during its rise, depending on the applied formulation. The temperature was measured until reaching a plateau (variations lower than $0.5^{\circ} \mathrm{C}$ for $10 \mathrm{~s}$ ). It can be seen that for the unfilled polyurethane foam, the temperature reached almost $90^{\circ} \mathrm{C}$. The introduction of waste rubber resulted in the decrease of the maximum temperature, which confirms our previous results [27]. Moreover, for the unfilled foam, faster heat build-up was observed, indicating the system's higher reactivity. As a result, the reference sample's rise time was the lowest among all foams and equaled $37 \mathrm{~s}$. The introduction of GTR, especially modified with oils, caused an elongation of rise time, even up to $45 \mathrm{~s}$ for $40 \mathrm{phr}$ content of oils. Such an effect was associated with the increased viscosity of the polyol mixture due to the presence of solid particles and the introduction of mostly non-reactive rapeseed oil (lack of hydroxyl groups). Its addition may also affect the reacting mixture's viscosity, inhibiting the nucleation of gas bubbles [38]. Despite the elongation of rise time, the temperature plateau was reached faster for composite foams, which was attributed to the partial replacement of polyurethane matrix with GTR. As a result, less reactive sites were present in the system, which caused reduced heat generation. Such an effect was especially pronounced for oil-modified GTR. 


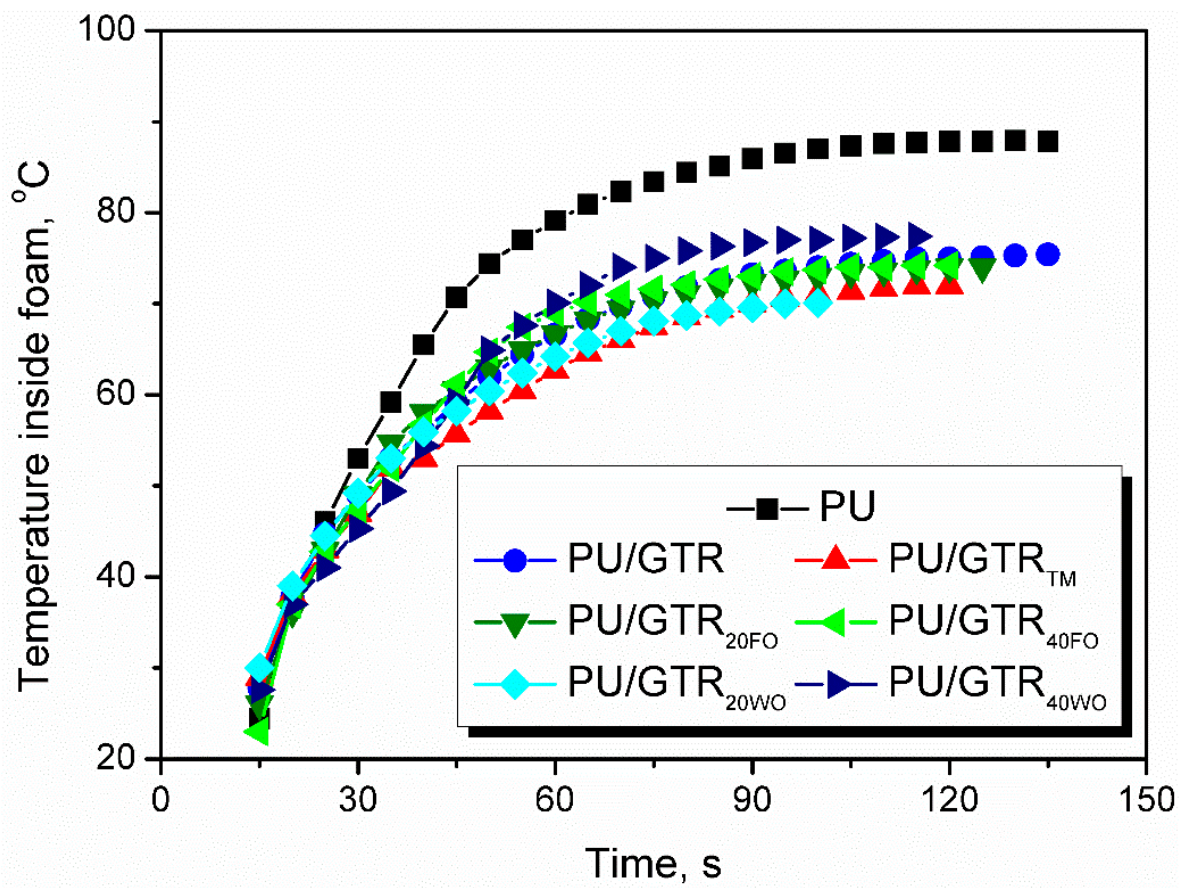

Figure 2. The impact of formulation on the temperature inside foam during polymerization.

In Figure 3, presented images show the cellular structure of prepared foams with information about the average cell diameter.

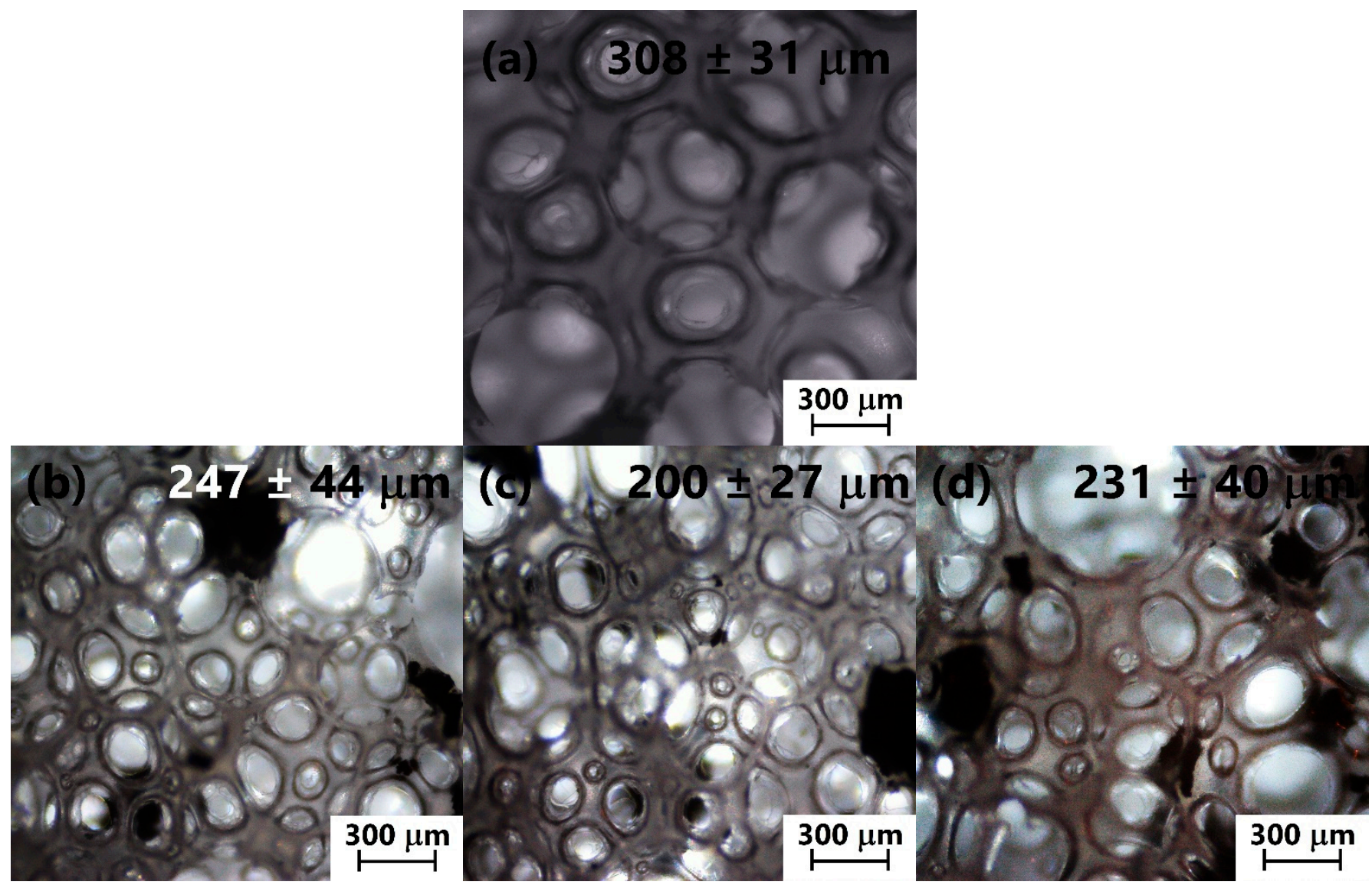

Figure 3. Cont. 


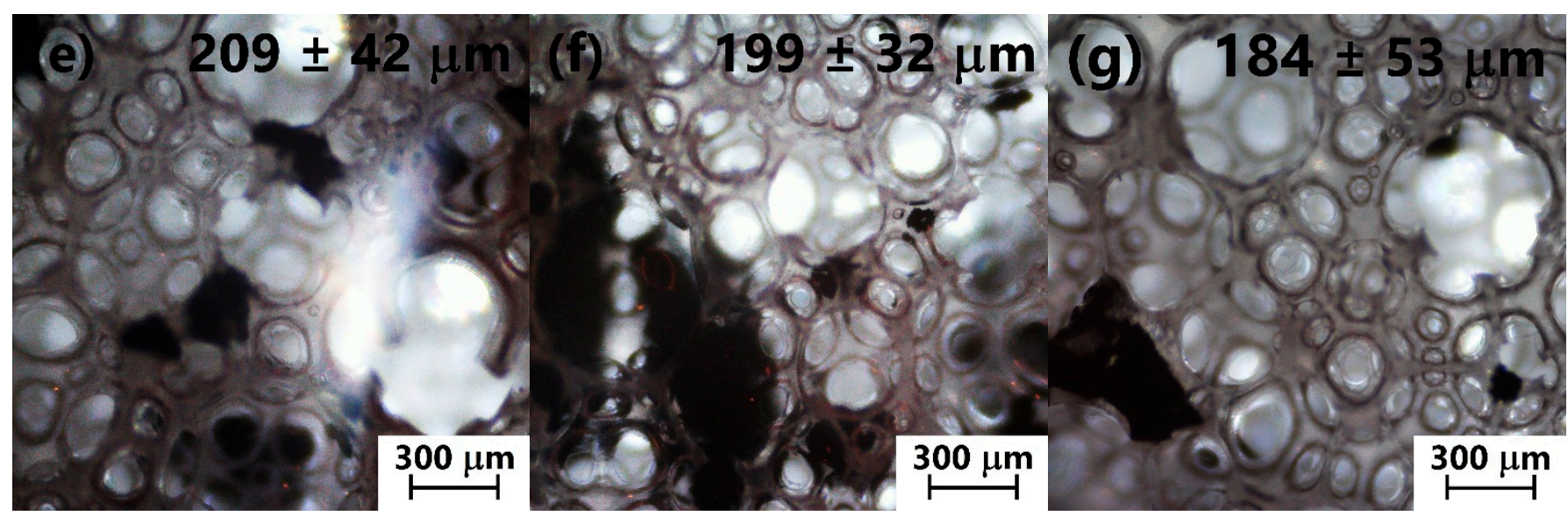

Figure 3. The exemplary images showing cellular structure of (a) PU, (b) PU/GTR, (c) PU/GTR $\mathrm{TM}_{1}(\mathbf{d}) \mathrm{PU} / \mathrm{GTR}_{20 \mathrm{FO}}$, (e) PU/GTR $40 \mathrm{FO}$, (f) PU/GTR 20 WO, and (g) PU/GTR 40 WO foams. PU: the neat foam without the addition of ground tire rubber (GTR).

It can be seen that the unfilled polyurethane matrix was characterized by a relatively regular structure. The incorporation of GTR caused significant changes in the foams structure. Irrespective of the GTR type, a decrease in the average cell size was noted and accompanied by the noticeable increase of structural heterogeneity. Such an effect can be attributed to the two different effects of GTR incorporation. First of all, the addition of solid particles into the polyol mixture caused a significant increase in its viscosity, which affected the volumetric expansion of foam [39]. This effect is typical for incorporating GTR into polyurethane foams' formulations and was noted in our previous papers [26,40]. In addition, Song et al. [41] indicated that foaming results in a more heterogeneous cellular structure at higher viscosities.

The second effect is the possible nucleating activity of solid particles due to the combined impact of surface development and the presence of functional groups on the GTR surface [42]. The surface development was mainly responsible for the decrease in average cell diameter after thermo-mechanical treatment of GTR. The shear forces acting on the solid particles during extrusion cause the increase in surface roughness, which was repeatedly proven in works [43-45]. As a result, the cell size was decreased, despite the lower content of functional groups able to react with isocyanates present on the GTR surface, which was expressed by the lower hydroxyl value $-37.8 \mathrm{mg} \mathrm{KOH} / \mathrm{g}$, compared to $61.7 \mathrm{mg} \mathrm{KOH} / \mathrm{g}$ for the unmodified GTR.

For oil-modified GTR, the functional groups' presence was rather more emphasized than the surface development, which was suggested by the higher hydroxyl values (see Table 1). The incorporation of oil-modified GTR enhanced the decrease in average cell size compared to the unmodified particles. Such a phenomenon may be associated with the possibly increased surface tension, so a higher amount of energy is required to form and grow cells [46]. Nevertheless, a noticeably stronger effect was observed for the waste-type oil, which could be attributed to the presence of lower-molecular weight fractions, possibly even glycerol and free fatty acids [47]. The lower molecular weight compounds present in the waste oil can also efficiently swell the rubber particles enhancing the interactions with the reacting mixture, which may beneficially influence the compatibility of GTR with foamed polyurethane matrix $[48,49]$. Qualitatively, a similar effect may be noted for the fresh oil. However, to a lower extent, the average cell size was bigger than for foam containing thermo-mechanically treated GTR. Nevertheless, more low-diameter cells were grown on the oil-treated GTR surface (see Figure 4). Similar effects associated with the presence of oils in polyurethane formulations were also noted by other researchers $[50,51]$. 


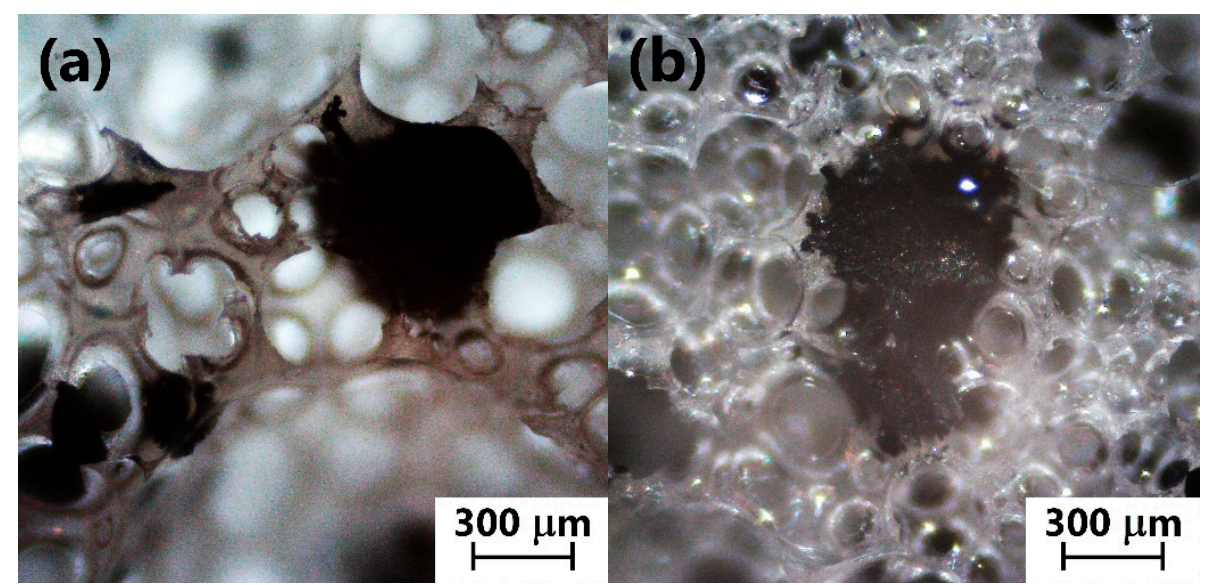

Figure 4. Growth of cells on the GTR surface for (a) PU/GTR and (b) PU/GTR 40 wO samples.

Figure 5 shows the influence of the GTR incorporation on the content of open cells in prepared foams. It can be seen that the highest open cell content was noted for the unfilled polyurethane matrix, while the GTR caused the partial closing of cells. Such an effect can be associated with the above-mentioned increase in polyol mixture viscosity and surface tension caused by GTR particles' presence and the addition of oils [38]. As a result, the presence of oils enhanced the number of smaller closed cells on the GTR surface, as shown in Figure 4. Such an effect may also be attributed to the higher hydroxyl values, hence the more possibilities to react with isocyanates present in the system. Figure $6 a, b$ show the structure of foams containing unmodified GTR particles. The places where the cellular structure was ruptured, resulting in open cells, are marked with red circles. Simultaneously, modification with $40 \mathrm{phr}$ of fresh and waste rapeseed oil caused a closing of low-diameter cells growing on the surface of GTR (blue circles in Figure $6 c, d$ ). The increase in the closed cell content may positively impact the strength and insulation performance of foams.

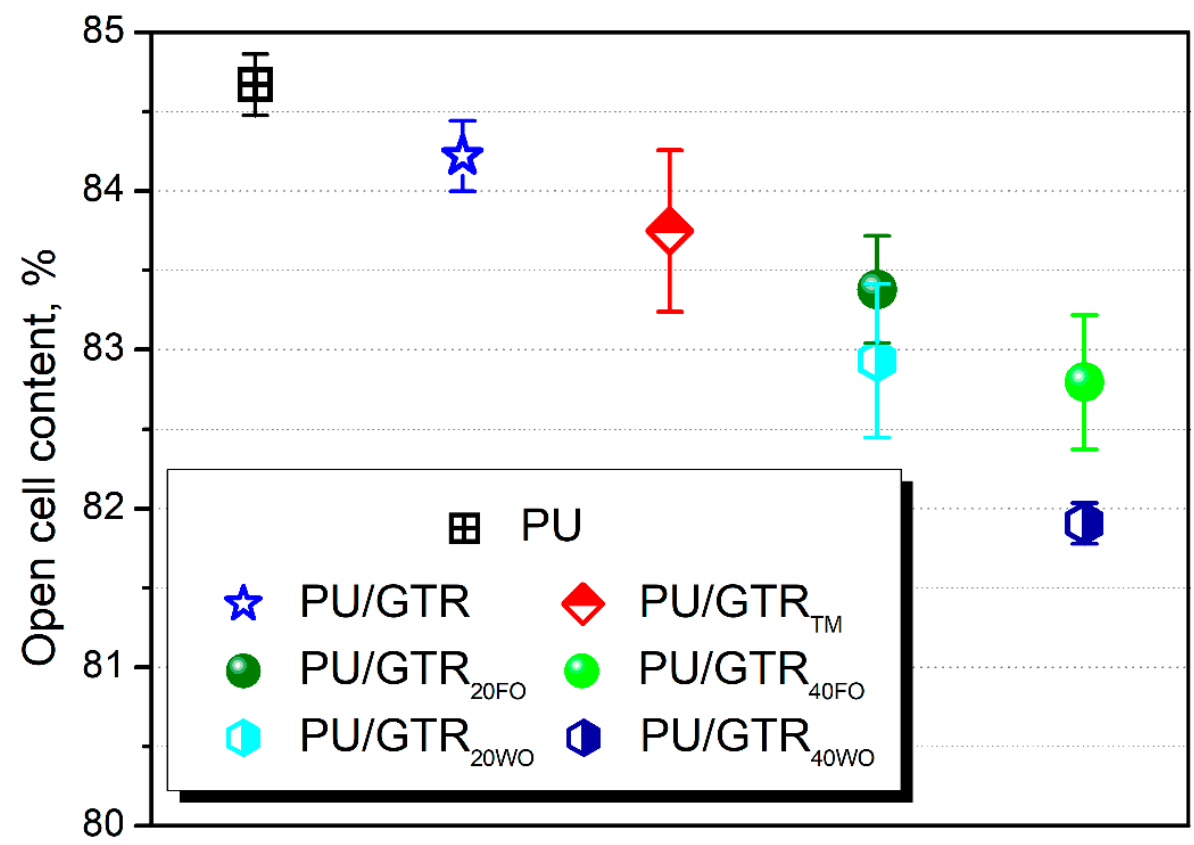

Figure 5. The open cell content of prepared polyurethane foams. 

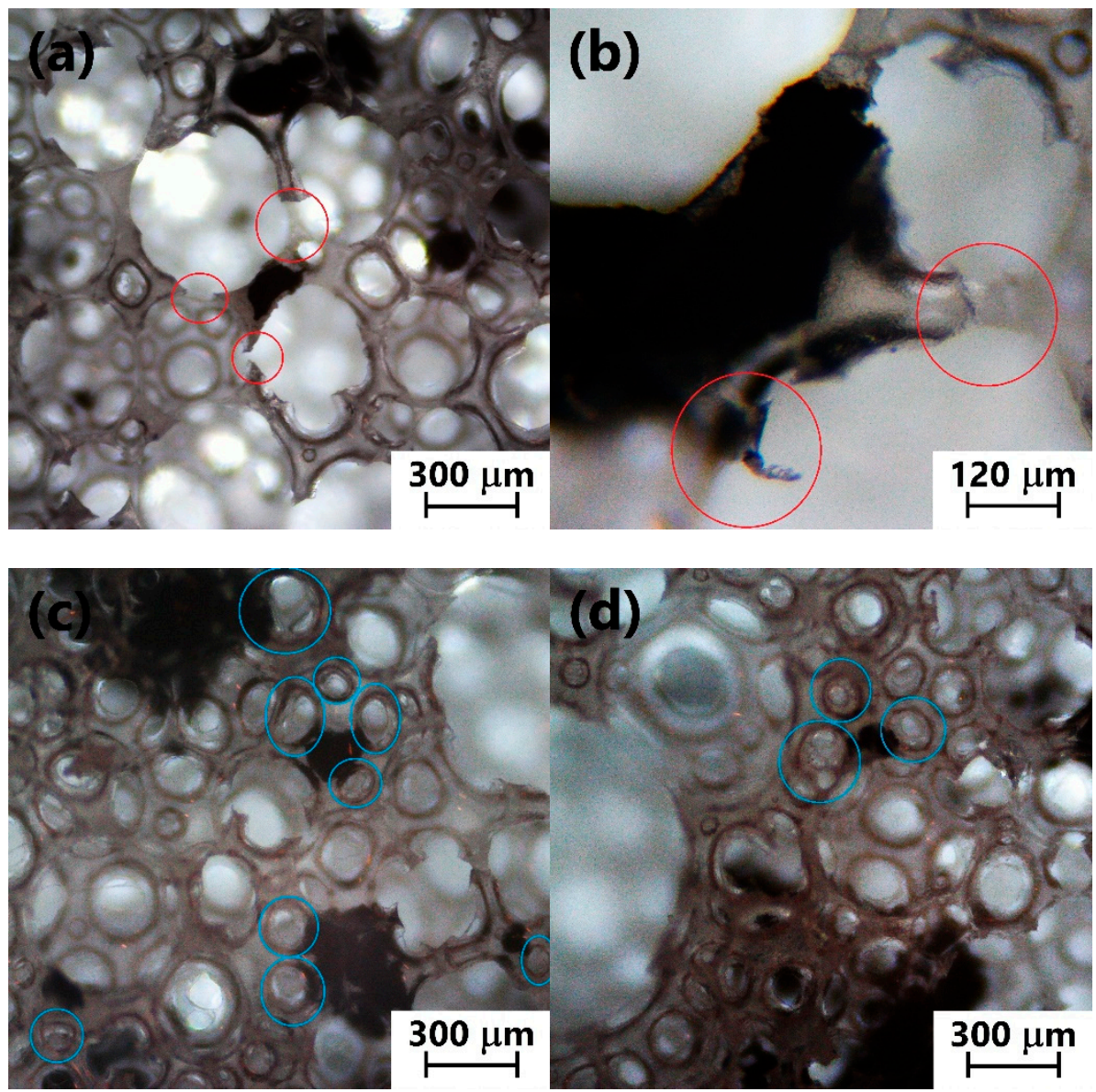

Figure 6. The effect of GTR type on the growth of open cells (red circles) and closed cells (blue circles) for $(\mathbf{a}, \mathbf{b})$ PU/GTR and $(\mathbf{c}, \mathbf{d})$ PU/GTR 40 WO foams.

Figure 7 shows the content of the sol fraction of prepared foams. This parameter can indicate the amount of non-crosslinked or unbound material, which can be extracted by solvent [52]. The low value of $2.3 \%$ noted for the unfilled PU foam indicates that the material was almost wholly reacted with only a small portion of extractives, which is typical for PU foams, especially at a lower isocyanate index [53]. The introduction of GTR caused an increase in sol fraction, which can be attributed to the presence of loose macromolecules in waste rubber particles and the unreacted portion of the polyurethane mixture [54]. When thermo-mechanically treated GTR was applied, the sol fraction content of foam was decreased. Generally, such treatments result in the partial devulcanization of GTR itself, increasing its sol fraction [55]. However, in the presented case, the devulcanization may provide additional possibilities for the interactions with the polyurethane matrix, which was also suggested by decreasing the average cell size and drop of open cell content.

Modification of GTR with two types of rapeseed oil showed a different impact on the foams' sol fraction content. For the fresh one, values exceeded $13 \%$, while for the waste oil, values were between 8 and $9 \%$, indicating the physical interactions at the interface. Such differences may be attributed to the changes in chemical structure occurring during the cooking of oil. Lower molecular weight compounds may enhance the interactions with polyurethane and facilitate the bonding with isocyanates, resulting in a higher crosslink degree [47].

The results of the static and dynamic mechanical tests are presented in Figures 8 and 9 and Table 3. It can be seen that the mechanical performance of the neat polyurethane foam was significantly affected by the incorporation of GTR particles. Nevertheless, all samples showed typical properties characteristic for flexible foams [56]. Considering compressive performance, the plateau phase can be noted after the initial rise of stress, which is termi- 
nated when densification of the structure occurs and stress gradually increases. Generally, the deterioration of the mechanical performance was noted, but the effect was also related to the applied matrix's relatively good performance. The changes in the mechanical properties, just as differences in the cellular structure, could be attributed to the surface development and content of functional groups (expressed by the hydroxyl value-see Table 1), resulting from applied GTR modifications. When the untreated GTR was applied as a filler, around a 50\% drop of compressive and tensile strength was noted, compared to the neat foam. The elongation at break was also reduced, which is often noted when the material's heterogeneity increased [57]. The treatment of GTR in the extruder resulted in enhancing the mechanical properties, which could be attributed to the above-mentioned surface development and the resulting decrease in particle size, despite the lower hydroxyl value. Moreover, values of the sol fraction content indicate the enhanced adhesion between GTR and PU.

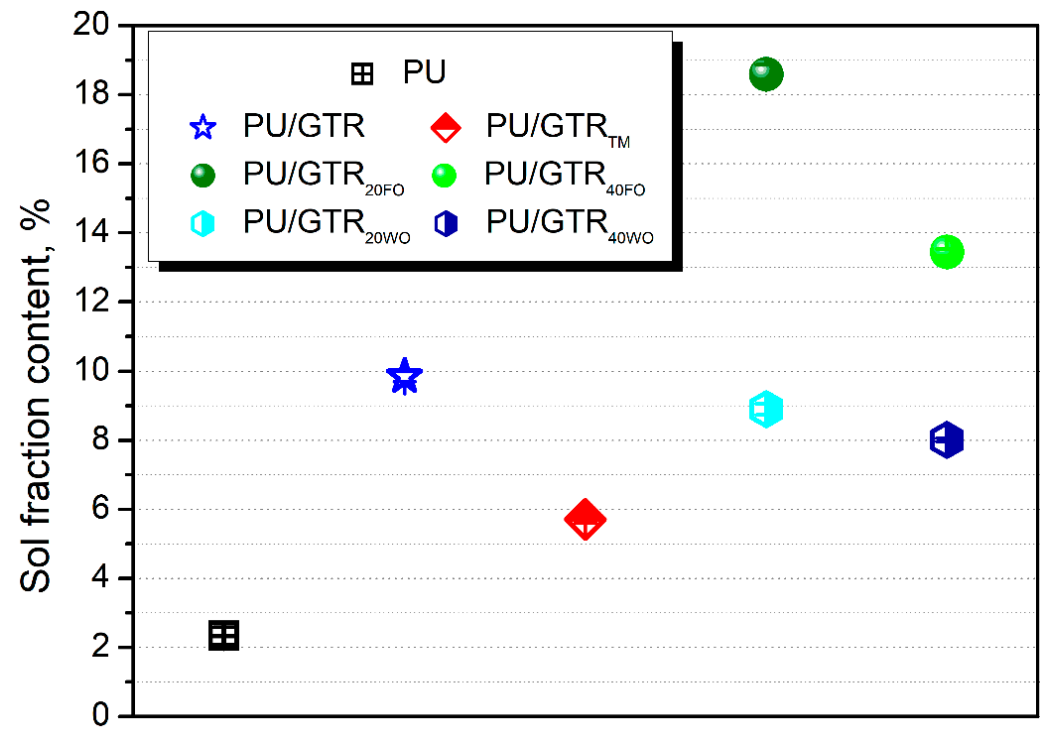

Figure 7. Sol fraction content for prepared polyurethane foams.

The mechanical performance of foams filled with oil-treated GTR was also in line with the sol fraction content, average cell diameter, and closed cell content. The values of tensile and compressive strength were about $100 \%$ higher when the waste oil was applied. As mentioned above, such an effect may be attributed to the higher crosslink degree, which is associated with the presence of lower molecular weight compounds generated during the cooking of oil. They could enhance the swelling of rubber and increase the strength of interactions with the polyurethane matrix. In addition, the lower average cell size and higher content of closed cells beneficially affected the mechanical performance. Such an effect was associated with the increase in the actual cross-section area during the application of force and was noted by other researchers [58]. Andersons et al. [59] found out that open-cell models of foamed materials highly underestimate the stiffness and strength of closed-cell foams, indicating that the opening of cells greatly impacts the mechanical performance. During compression, the strength of foamed material results from the buckling of cell walls and structure densification. According to the literature data [60], the increase in cell size implicates cell walls' thickening and decreased the struts fraction. As a result, the strength that foams can withstand decreases with the rise of average cell size. Considering the tensile performance of flexible foams, the motions of walls and struts occur during tension, so the walls are aligned along the stress direction. Thicker cell walls of foams with smaller particle sizes can withstand higher forces. 




Figure 8. Compressive strength of prepared polyurethane foams.

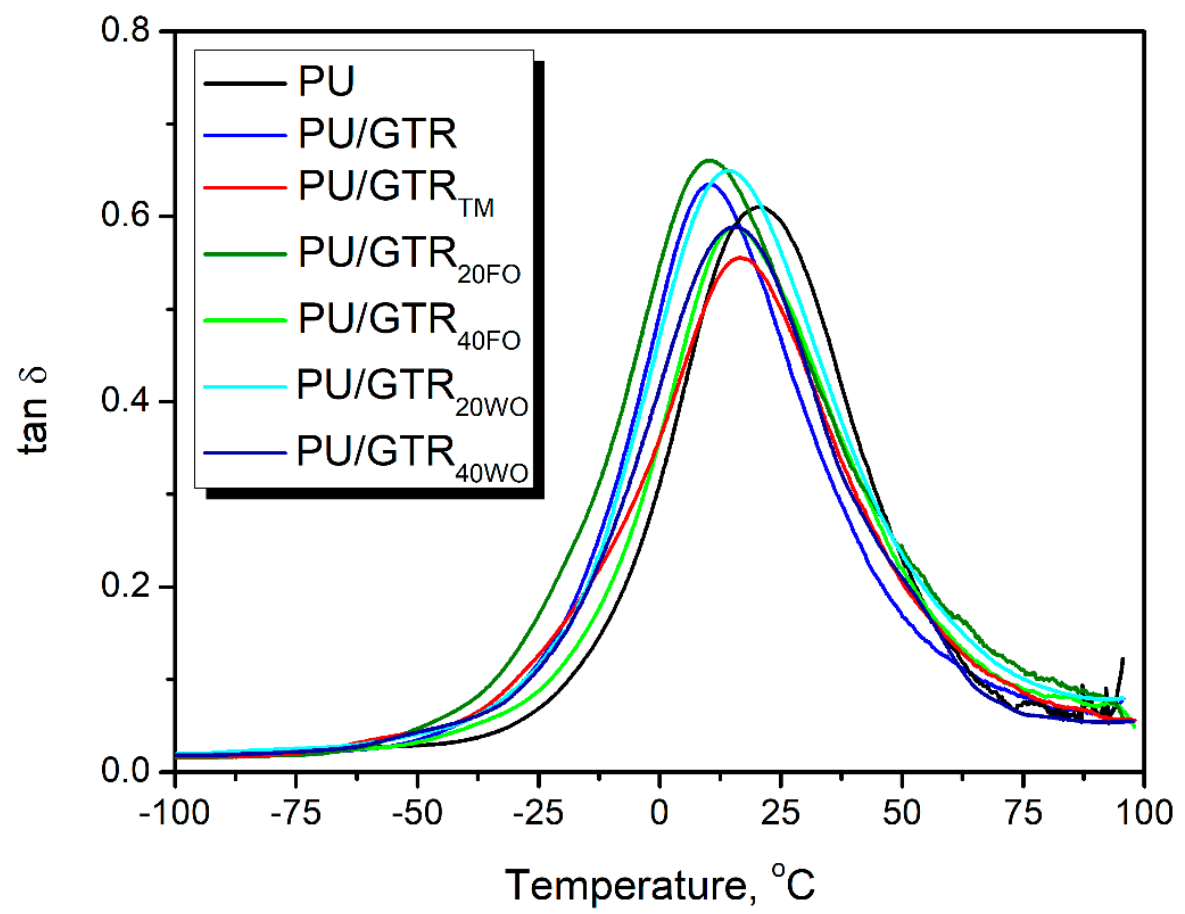

Figure 9. Temperature plot of $\tan \delta$ for prepared polyurethane foams. 
Table 3. The results of static and dynamic mechanical analysis of prepared polyurethane foams.

\begin{tabular}{|c|c|c|c|c|c|c|c|c|}
\hline \multirow{2}{*}{ Sample } & \multicolumn{2}{|c|}{$\begin{array}{c}\text { Compressive Strength at } 60 \% \\
\text { Deformation }\end{array}$} & \multirow{2}{*}{$\begin{array}{l}\text { Tensile } \\
\text { Strength, } \\
\text { kPa }\end{array}$} & \multirow{2}{*}{$\begin{array}{l}\text { Elongation } \\
\text { at Break, \% }\end{array}$} & \multirow{2}{*}{$\begin{array}{l}\mathrm{E}^{\prime} \text { at } 22{ }^{\circ} \mathrm{C}, \\
\mathrm{kPa}\end{array}$} & \multirow{2}{*}{$\begin{array}{l}\mathrm{E}^{\prime \prime} \text { at } 22{ }^{\circ} \mathrm{C}, \\
\mathrm{kPa}\end{array}$} & \multirow{2}{*}{$\begin{array}{l}\tan \delta \text { at } \\
22^{\circ} \mathrm{C}\end{array}$} & \multirow{2}{*}{$\mathrm{T}_{\mathrm{g}},{ }^{\circ} \mathrm{C}$} \\
\hline & $\begin{array}{l}\text { Measured, } \\
\text { kPa }\end{array}$ & $\begin{array}{l}\text { Normalized, } \\
\mathrm{kPa} \cdot \mathrm{m}^{3} / \mathrm{kg}\end{array}$ & & & & & & \\
\hline Matrix & $77+7$ & 0.37 & $230+6$ & $195+4$ & 1358 & 834 & 0.61 & 20.7 \\
\hline PU/GTR & $38+2$ & 0.18 & $128+5$ & $167+2$ & 627 & 323 & 0.52 & 10.5 \\
\hline $\mathrm{PU} / \mathrm{GTR}_{\mathrm{TM}}$ & $52+2$ & 0.26 & $156+8$ & $171+5$ & 1049 & 558 & 0.53 & 16.6 \\
\hline $\mathrm{PU} / \mathrm{GTR}_{20 \mathrm{FO}}$ & $19+1$ & 0.09 & $77+1$ & $174+2$ & 379 & 213 & 0.56 & 10.3 \\
\hline $\mathrm{PU} / \mathrm{GTR}_{40 \mathrm{FO}}$ & $40+4$ & 0.19 & $128+4$ & $178+1$ & 854 & 472 & 0.55 & 15.9 \\
\hline PU/GTR $20 W O$ & $45+2$ & 0.22 & $154+13$ & $169+7$ & 935 & 568 & 0.60 & 14.1 \\
\hline PU/GTR 40 WO & $97+3$ & 0.46 & $197+12$ & $178+5$ & 1023 & 582 & 0.55 & 15.4 \\
\hline
\end{tabular}

Table 3 also provided the parameters determined by the dynamic mechanical analysis at $22{ }^{\circ} \mathrm{C}$ (the temperature during the static tests). They can be used to interpret the static mechanical performance properly. It can be seen that the introduction of GTR into the PU matrix resulted in a significant drop in stiffness, which may be attributed to the disturbance in structure and presence of loose macromolecules (higher sol fraction content). When thermo-mechanically treated GTR was used, and interactions with matrix were stronger, and the stiffness was also increased. The oil treatment caused a reduction in stiffness compared to thermo-mechanical treatment. Generally, the sensitivity of prepared materials mechanical performance to the type of introduced GTR may be explained by values of glass transition temperature $\left(\mathrm{T}_{\mathrm{g}}\right)$, which are determined as the tan $\delta$ peak's temperature position, often called the damping factor. The polymers' mechanical performance is susceptible to the glass transition, which occurs in a certain temperature range rather than isothermally [61,62]. For better visualization, Figure 9 shows the temperature plot of the damping factor for prepared materials. It can be seen that for the unfilled foam, the value of $\mathrm{T}_{\mathrm{g}}$ equaled $20.7^{\circ} \mathrm{C}$, which is very close to the temperature during mechanical tests. Its shift toward lower temperatures by $4.1-10.4{ }^{\circ} \mathrm{C}$ may noticeably affect the mechanical performance because of the increase in molecular motions. Hatakeyama et al. [63] found that for the flexible polyurethane foams, variations of the $T_{g}$ in the range of $0-20{ }^{\circ} \mathrm{C}$ may result in even a $40 \%$ change of compressive strength.

Figure 10 presents the course of thermal degradation of modified GTR as well as prepared composite foams during thermogravimetric analysis, together with the differential thermogravimetric curves. Moreover, results are summarized in Table 4.

For the unmodified and thermo-mechanically treated GTR, the course of thermal decomposition was relatively similar and included two noticeable decomposition steps. The first one, around $378-390^{\circ} \mathrm{C}\left(\mathrm{T}_{\max 4}\right)$, was associated with the decomposition of natural rubber, while the second one at $431-443{ }^{\circ} \mathrm{C}\left(\mathrm{T}_{\max 5}\right)$ was attributed to the decomposition of styrene-butadiene rubber [64]. These are the two main components of the ground tire rubber that originated from waste tires.

The GTR modification with the fresh rapeseed oil resulted in the noticeable enhancement of its thermal stability. Such an effect was related to the stability of the applied modifier. Generally, rapeseed oil shows a one-step decomposition process related to the degradation of triglycerides, which starts around $325^{\circ} \mathrm{C}$, reaches a maximum rate of around $440{ }^{\circ} \mathrm{C}$, and ends at $500{ }^{\circ} \mathrm{C}$ [65]. As a result, the DTG curves of modified rubbers were noticeably affected. The peaks $\mathrm{T}_{\max 4}$ and $\mathrm{T}_{\max 5}$ were shifted by $3.4-11.0$ and $9.8-11.7^{\circ} \mathrm{C}$, respectively, toward higher temperatures. Moreover, the rate of decomposition at $\mathrm{T}_{\max 4}$ was noticeably affected.

Treatment of GTR with the waste rapeseed oil resulted in similar changes in qualitative terms. Nevertheless, the thermal stability was slightly lower compared to the use of fresh oil. Such an effect may be associated with the partial decomposition of oil during its primary use and the resulting presence of lower-molecular weight compounds, whose onset of degradation was lower. It was also mirrored in the temperature positions of $T_{\max 4}$ and $\mathrm{T}_{\max 5}$ peaks at differential thermogravimetric curves. 
As a result of the above-mentioned changes, the incorporation of ground tire rubber enhanced the thermal stability of neat polyurethane foam. The onset of thermal decomposition, which is attributed to the temperature of $2 \mathrm{wt} \%$ mass loss, was shifted from $215.0{ }^{\circ} \mathrm{C}$ for a neat PU matrix by $13.4-24.6^{\circ} \mathrm{C}$, depending on the GTR type. Such an effect was associated with the higher thermal stability of GTR, which was also noticeably influenced by the applied modifications. Except for the simple enhancement of thermal stability, the incorporation of GTR caused significant changes in the course of thermal decomposition, which were expressed by the differential thermogravimetric curves. For neat polyurethane foam, five noticeable peaks can be observed. The first two, at 187.7 and $227.6^{\circ} \mathrm{C}$, are associated with the dissociation of urethane bonds, accounting for the hard segments of polyurethane [66]. They are relatively small because of the low value of NCO:OH ratio (1:1) applied during foams preparation. Moreover, two separate peaks can be related to the used foam formulation, which contained two polyols and a small glycerol portion. As a result, the structure of hard segments was diverse. The magnitude of these peaks was lowered for composite foams, and their positions were shifted toward higher temperatures. In the case of unfilled PU foam, the composition containing two different polyols also resulted in the presence of two separate peaks attributed to the decomposition of soft segments- $\mathrm{T}_{\max 3}$ and $\mathrm{T}_{\max 4}$, at 346.7 and $393.4^{\circ} \mathrm{C}$, respectively. This separation was also noted for composites containing unmodified and thermo-mechanically treated GTR. Then, the peak $\mathrm{T}_{\max 4}$ was overlapped with the decomposition of natural rubber. Nevertheless, when oil-modified GTR was incorporated, the separation between overlapping $\mathrm{T}_{\max 3}$ and $\mathrm{T}_{\max 4}$ peaks was not as visible.
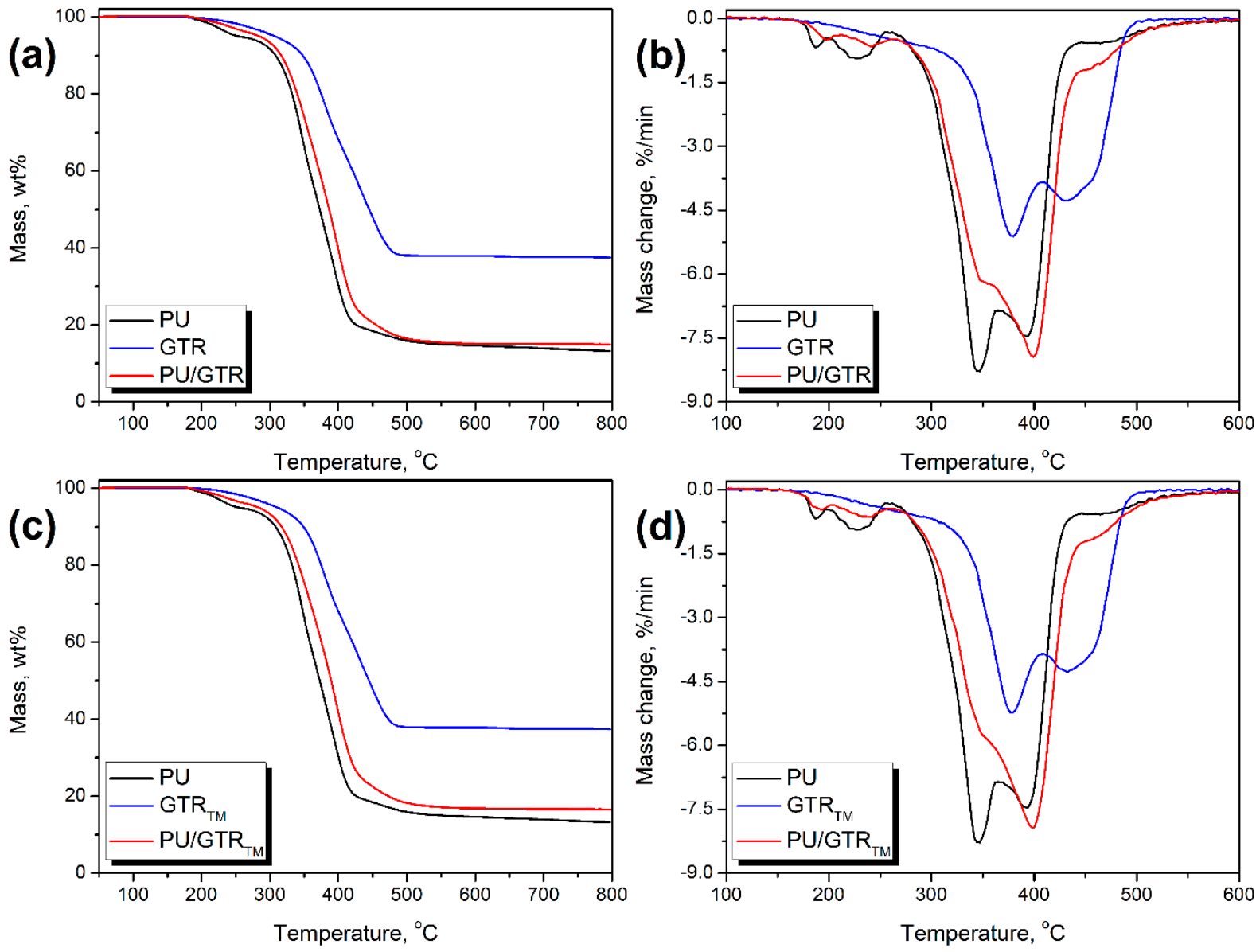

Figure 10. Cont. 

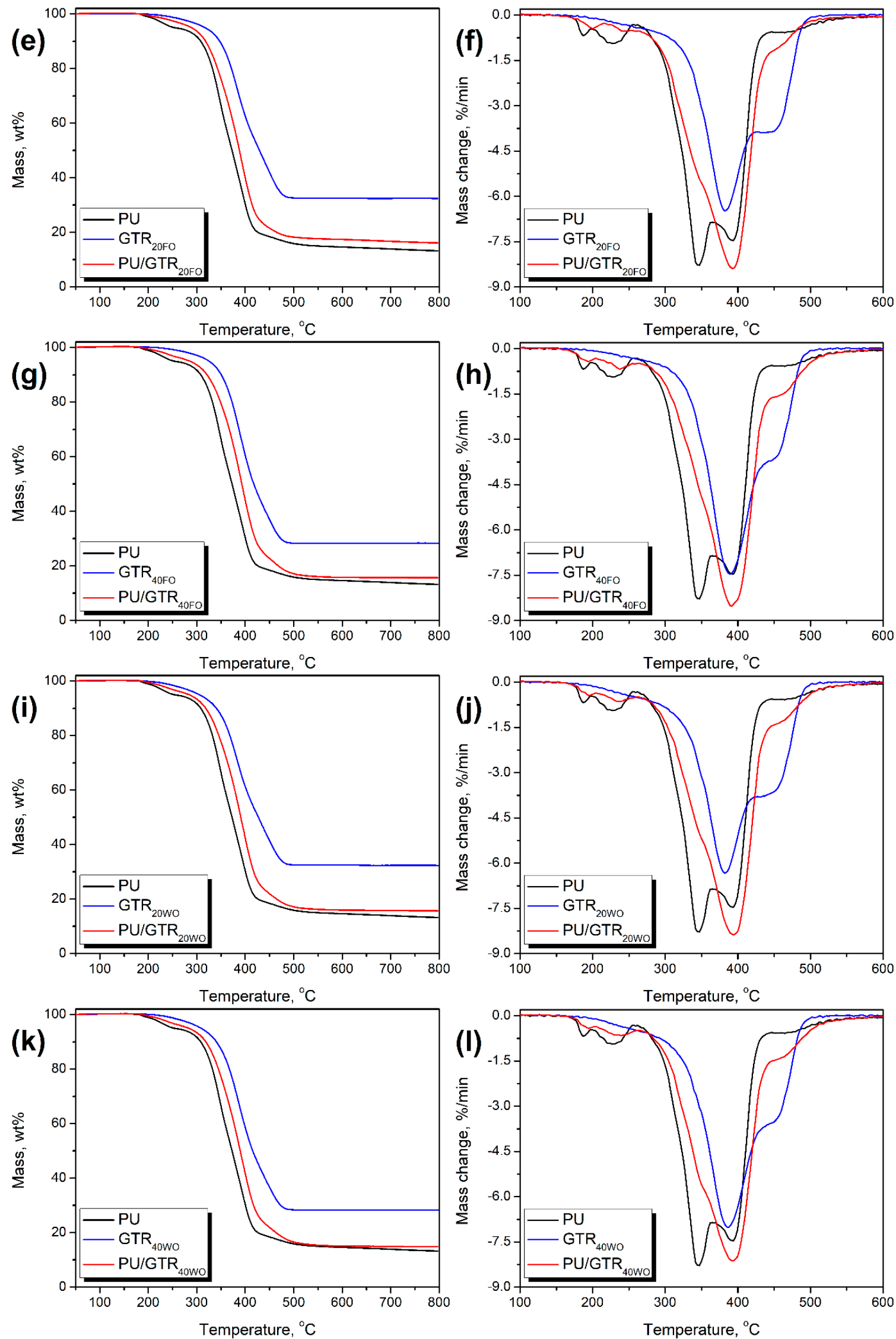

Figure 10. The results of thermogravimetric analysis for of $(\mathbf{a}, \mathbf{b}) \mathrm{PU} / \mathrm{GTR},(\mathbf{c}, \mathbf{d}) \mathrm{PU} / \mathrm{GTR}_{\mathrm{TM}},(\mathbf{e}, \mathbf{f}) \mathrm{PU} / \mathrm{GTR} 20 \mathrm{FO},(\mathbf{g}, \mathbf{h})$ $\mathrm{PU} / \mathrm{GTR}_{40 \mathrm{FO}},(\mathbf{i}, \mathbf{j}) \mathrm{PU} / \mathrm{GTR}_{20 \mathrm{WO}}$, and $(\mathbf{k}, \mathbf{l}) \mathrm{PU} / \mathrm{GTR}_{40 \mathrm{WO}}$ foams. 
Table 4. The results of the thermogravimetric analysis for prepared polyurethane foams and applied ground tire rubbers.

\begin{tabular}{|c|c|c|c|c|c|c|c|c|c|c|}
\hline Sample & $\mathrm{T}_{-2},{ }^{\circ} \mathrm{C}$ & $\mathbf{T}_{-5},{ }^{\circ} \mathbf{C}$ & $\mathrm{T}_{-10},{ }^{\circ} \mathrm{C}$ & $\mathrm{T}_{-50},{ }^{\circ} \mathrm{C}$ & $\begin{array}{c}\text { Residue, } \\
\text { wt } \%\end{array}$ & $\mathrm{~T}_{\max 1},{ }^{\circ} \mathrm{C}$ & $\mathrm{T}_{\max 2,}{ }^{\circ} \mathrm{C}$ & $\mathrm{T}_{\max 3},{ }^{\circ} \mathrm{C}$ & $\mathrm{T}_{\max 4},{ }^{\circ} \mathrm{C}$ & $\mathrm{T}_{\max 5},{ }^{\circ} \mathrm{C}$ \\
\hline Matrix & 215.0 & 253.5 & 308.2 & 372.5 & 13.2 & 187.7 & 227.6 & 346.7 & 393.4 & 456.8 \\
\hline GTR & 256.6 & 307.2 & 347.9 & 444.7 & 37.5 & - & - & - & 379.0 & 431.2 \\
\hline PU/GTR & 232.5 & 284.3 & 316.2 & 386.3 & 14.9 & 198.0 & 241.1 & 349.0 & 399.5 & 454.0 \\
\hline $\mathrm{GTR}_{\mathrm{TM}}$ & 261.1 & 310.2 & 348.9 & 444.4 & 37.4 & - & - & - & 378.2 & 431.8 \\
\hline $\mathrm{PU} / \mathrm{GTR}_{\mathrm{TM}}$ & 228.4 & 283.0 & 316.7 & 389.3 & 16.5 & 192.9 & 240.3 & 349.2 & 398.8 & 455.0 \\
\hline $\mathrm{GTR}_{20 \mathrm{FO}}$ & 269.5 & 316.6 & 347.2 & 429.3 & 32.4 & - & - & - & 382.4 & 442.9 \\
\hline $\mathrm{PU} / \mathrm{GTR}_{20 \mathrm{FO}}$ & 239.6 & 289.0 & 317.9 & 387.8 & 16.1 & 199.9 & 238.9 & - & 393.3 & 455.9 \\
\hline $\mathrm{GTR}_{40 \mathrm{FO}}$ & 283.7 & 325.0 & 350.3 & 417.4 & 27.7 & - & - & - & 389.2 & 441.6 \\
\hline $\mathrm{PU} / \mathrm{GTR}_{40 \mathrm{FO}}$ & 233.1 & 285.5 & 320.9 & 392.8 & 15.6 & 193.7 & 237.1 & - & 390.9 & 453.9 \\
\hline $\mathrm{GTR}_{20 W O}$ & 259.9 & 305.1 & 340.4 & 427.0 & 32.3 & - & - & - & 381.9 & 440.6 \\
\hline PU/GTR $20 W O$ & 231.7 & 284.0 & 318.3 & 390.7 & 15.7 & 195.1 & 237.3 & - & 393.5 & 454.1 \\
\hline $\mathrm{GTR}_{40 \mathrm{WO}}$ & 267.1 & 308.8 & 340.4 & 415.3 & 27.9 & - & - & - & 386.3 & 440.6 \\
\hline PU/GTR $40 W O$ & 231.4 & 283.4 & 318.5 & 389.5 & 14.9 & 194.2 & 239.9 & - & 393.2 & 453.6 \\
\hline
\end{tabular}

Generally, from the presented results of a thermogravimetric analysis, it can be seen that the application of ground tire rubber as a filler for the flexible polyurethane foam may efficiently improve their thermal stability. Moreover, by the proper modification, the level of enhancement may be adjusted.

\section{Conclusions}

In the presented work, we aimed to investigate the impact of the rapeseed oil-assisted thermo-mechanical treatment of GTR using the reactive extrusion process on the processing, structure, and performance of flexible foamed polyurethane-based composites. Two types of rapeseed oil were applied, fresh oil and waste obtained from a local restaurant. The introduction of unmodified and treated GTR caused a slight elongation of processing times and significantly reduced processing temperatures. It was mostly attributed to the increased viscosity of the polyol mixture, which was caused by the introduction of solid particles and mostly non-reactive rapeseed oil (lack of hydroxyl groups). Moreover, the presence of oil probably increased the surface tension in reacting polyurethane systems, which resulted in a significant decrease in average cell size and increased the content of closed cells. Such an effect was mostly pronounced when waste-type oil was applied as modifiers. Contrary to the fresh oil, waste oil contains noticeably higher amounts of lowermolecular weight compounds, which can efficiently swell the GTR particles and strengthen the interfacial interactions. The mechanical properties of composites were directly affected by their structural parameters. Thermo-mechanical treatment of GTR caused a significant improvement of the compressive and tensile strength of foams. Introduction of the fresh rapeseed oil, despite the swelling of rubber, deteriorated the mechanical performance of foams, which could be related to the low amount of reactive sites enabling interactions with the polyurethane system. On the contrary, waste oil, containing compounds generated during cooking, improved the interfacial adhesion and provided superior performance compared to the GTR modified without oils. The applied GTR treatments also affected composites' dynamic mechanical performance, which was associated with changes in the glass transition temperature, whose values were close to the ambient temperature during mechanical tests. Another beneficial effect of GTR incorporation into flexible polyurethane foam was the improvement in thermal stability. The onset of thermal decomposition was shifted for $13-25^{\circ} \mathrm{C}$ toward higher temperatures, which was due to the high stability of GTR. Generally, the reported results show that the thermo-mechanical treatment of GTR in the reactive extrusion process should be considered a promising method for enhancement of the interfacial interactions in foamed polyurethane-based composites. By the adjustment of treatment conditions and type of applied modifier, composites with the desired structure and performance could be obtained. Future works in this area should be focused on 
the incorporation of new modifiers of GTR, evaluation of the ecological harmfulness of the process, as well as more in-depth evaluation of the changes during the processing of polyurethane systems.

Author Contributions: Conceptualization, Ł.Z., K.F. and A.H.; methodology, P.K. and Ł.Z.; software, A.H.; validation, P.K., K.F. and A.H.; formal analysis, Ł.Z.; investigation, P.K., A.O. and P.B.; resources, K.F. and A.H.; data curation, A.O. and P.B.; writing-original draft preparation, A.H.; writingreview and editing, A.O. and K.F.; visualization, A.H.; supervision, A.H.; project administration, A.H.; funding acquisition, A.H. All authors have read and agreed to the published version of the manuscript.

Funding: This work was supported by The National Centre for Research and Development (NCBR, Poland) in the frame of LIDER/3/0013/L-10/18/NCBR/2019 project-Development of technology for the manufacturing of foamed polyurethane-rubber composites for the use as damping materials.

Institutional Review Board Statement: Not applicable.

Informed Consent Statement: Not applicable.

Data Availability Statement: Data are contained within the article. The data presented in this study are available in Structural changes and their implications in foamed flexible polyurethane composites filled with rapeseed oil-treated ground tire rubber.

Conflicts of Interest: The authors declare no conflict of interest.

\section{References}

1. Mokhtar, F.N.; Abdel Rehim, I.V.; Mahmoud, E.A. Applicability of using recycled rubber-Tire materials for acoustic insulation in barriers of residential areas in Egypt. ARPN J. Eng. Appl. Sci. 2017, 12, 806-820.

2. Hidalgo-Signes, C.; Garzón-Roca, J.; Grima-Palop, J.M.; Insa-Franco, R. Use of rubber shreds to enhance attenuation of railway sub-ballast layers made of unbound aggregates. Mater. Construcción 2017, 67, 115. [CrossRef]

3. Shu, X.; Huang, B. Recycling of waste tire rubber in asphalt and portland cement concrete: An overview. Constr. Build. Mater. 2014, 67, 217-224. [CrossRef]

4. Yoon, S.; Prezzi, M.; Siddiki, N.Z.; Kim, B. Construction of a test embankment using a sand-tire shred mixture as fill material. Waste Manag. 2006, 26, 1033-1044. [CrossRef]

5. Thomas, B.S.; Gupta, R.C. A comprehensive review on the applications of waste tire rubber in cement concrete. Renew. Sustain. Energy Rev. 2016, 54, 1323-1333. [CrossRef]

6. Echterhof, T. Review on the use of alternative carbon sources in EAF steelmaking. Metals 2021, 11, 222. [CrossRef]

7. Dankwah, J.R.; Koshy, P.; O'Kane, P.; Sahajwalla, V. Reduction of FeO in EAF steelmaking slag by blends of metallurgical coke and end-of-life tyre. Steel Res. Int. 2012, 83, 766-774. [CrossRef]

8. Tire Incineration. Energy Justice Network. Available online: http:/ / www.energyjustice.net/tires\#25 (accessed on 3 February 2021).

9. Amari, T.; Themelis, N.J.; Wernick, I.K. Resource recovery from used rubber tires. Resour. Policy 1999, 25, 179-188. [CrossRef]

10. Ramarad, S.; Khalid, M.; Ratnam, C.; Chuah, A.L.; Rashmi, W. Waste tire rubber in polymer blends: A review on the evolution, properties and future. Prog. Mater. Sci. 2015, 72, 100-140. [CrossRef]

11. De Sousa, F.D.B.; Scuracchio, C.H.; Hu, G.; Hoppe, S. Effects of processing parameters on the properties of microwavedevulcanized ground tire rubber/polyethylene dynamically revulcanized blends. J. Appl. Polym. Sci. 2016, 133, 43503. [CrossRef]

12. Aoudia, K.; Azem, S.; Hocine, N.A.; Gratton, M.; Pettarin, V.; Seghar, S. Recycling of waste tire rubber: Microwave devulcanization and incorporation in a thermoset resin. Waste Manag. 2017, 60, 471-481. [CrossRef] [PubMed]

13. Hernández, E.H.; Gámez, J.F.H.; Cepeda, L.F.; Muñoz, E.J.C.; Corral, F.S.; Rosales, S.G.S.; Velázquez, G.N.; Morones, P.G.; Martínez, D.I.S. Sulfuric acid treatment of ground tire rubber and its effect on the mechanical and thermal properties of polypropylene composites. J. Appl. Polym. Sci. 2017, 134, 44864. [CrossRef]

14. Cheng, X.; Long, D.; Huang, S.; Li, Z.; Guo, X. Time effectiveness of the low-temperature plasma surface modification of ground tire rubber powder. J. Adhes. Sci. Technol. 2015, 29, 1330-1340. [CrossRef]

15. Colom, X.; Faliq, A.; Formela, K.; Cañavate, J. FTIR spectroscopic and thermogravimetric characterization of ground tyre rubber devulcanized by microwave treatment. Polym. Test. 2016, 52, 200-208. [CrossRef]

16. Rungrodnimitchai, S.; Kotatha, D. Chemically modified ground tire rubber as fluoride ions adsorbents. Chem. Eng. J. 2015, 282, 161-169. [CrossRef]

17. Formela, K.; Cysewska, M.; Haponiuk, J.T. Thermomechanical reclaiming of ground tire rubber via extrusion at low temperature: Efficiency and limits. J. Vinyl Addit. Technol. 2014, 22, 213-221. [CrossRef]

18. Tzoganakis, C. Reactive extrusion of polymers: A review. Adv. Polym. Technol. 1989, 9, 321-330. [CrossRef]

19. Moad, G. Chemical modification of starch by reactive extrusion. Prog. Polym. Sci. 2011, 36, 218-237. [CrossRef] 
20. Przybysz-Romatowska, M.; Haponiuk, J.; Formela, K. Reactive extrusion of biodegradable aliphatic polyesters in the presence of free-radical-initiators: A review. Polym. Degrad. Stab. 2020, 182, 109383. [CrossRef]

21. Swinarew, B. Poliuretany-Nowoczesne wszechstronne materiały. Część II—Pianki poliuretanowe. Przetw. Tworzyw 2015, 5, 428-434. (In Polish)

22. Papiński, J.; Żabski, L. Zrozumieć poliuretany. Mater. Bud. 2011, 1, 57-58. (In Polish)

23. Hejna, A.; Kosmela, P.; Olszewski, A.; Zedler, Ł.; Formela, K. The impact of ground tire rubber treatment on the thermal conductivity of flexible polyurethane/ground tire rubber composites. In Scientific Collection «InterConf», (38), Proceedings of the 1st International Scientific and Practical Conference «Science, Education, Innovation: Topical Issues and Modern Aspects», Tallin, Estonia, 16-18 December 2020; Uhingu Teadus Juhatus: Tallin, Estonia, 2020; pp. 1062-1068.

24. Barnat, W.; Miedzińska, D.; Niezgoda, T. Pianki poliuretanowe-Właściwości, zastosowania, recykling. Arch. Gospod. Odpa-dami Ochr. Sr. 2011, 13, 13-17. (In Polish)

25. Piszczyk, Ł.; Hejna, A.; Danowska, M.; Strankowski, M.; Formela, K. Polyurethane/ground tire rubber composite foams based on polyglycerol: Processing, mechanical and thermal properties. J. Reinf. Plast. Compos. 2015, 34, 708-717. [CrossRef]

26. Piszczyk, Ł.; Hejna, A.; Formela, K.; Danowska, M.; Strankowski, M. Effect of ground tire rubber on structural, mechanical and thermal properties of flexible polyurethane foams. Iran. Polym. J. 2014, 24, 75-84. [CrossRef]

27. Hejna, A.; Olszewski, A.; Zedler, Ł.; Kosmela, P.; Formela, K. The Impact of Ground Tire Rubber Oxidation with $\mathrm{H}_{2} \mathrm{O}_{2}$ and $\mathrm{KMnO}_{4}$ on the structure and performance of flexible polyurethane/ground tire rubber composite foams. Materials 2021, 14, 499. [CrossRef]

28. Hejna, A.; Kosmela, P.; Olszewski, A.; Zedler, Ł.; Formela, K. Determination of the Hydroxyl Number of Ground Tire Rubber Particles Via Modified Test Method for Isocyanate Groups. In Scientific Collection «InterConf», (39), Proceedings of the 8th International Scientific and Practical Conference «Science and Practice: Implementation to Modern Society», Manchester, UK, 26-28 December 2020; Peal Press Ltd.: Manchester, UK, 2020; pp. 1535-1543.

29. Cachaço, A.G.; Afonso, M.D.; Pinto, M.L. New applications for foam composites of polyurethane and recycled rubber. J. Appl. Polym. Sci. 2013, 129, 2873-2881. [CrossRef]

30. Gayathri, R.; Vasanthakumari, R.; Padmanabhan, C. Sound absorption, thermal and mechanical behavior of polyurethane foam modified with nano silica, nano clay and crumb rubber fillers. Int. J. Sci. Eng. Res. 2013, 4, 301-308.

31. Zhang, X.; Lu, Z.; Tian, N.; Li, H. Mechanochemical devulcanization of ground tire rubber and its application in acoustic absorbent polyurethane foamed composites. J. Appl. Polym. Sci. 2013, 127, 4006-4014. [CrossRef]

32. Fazli, A.; Rodrigue, D. Recycling Waste Tires into Ground Tire Rubber (GTR)/Rubber Compounds: A Review. J. Compos. Sci. 2020, 4, 103. [CrossRef]

33. Zedler, Ł.; Kosmela, P.; Olszewski, A.; Burger, P.; Formela, K.; Hejna, A. Recycling of waste rubber by thermo-mechanical treatment in a twin-screw extruder. Proceedings 2020, 69, 10. [CrossRef]

34. Hejna, A.; Kosmela, P.; Klein, M.; Formela, K.; Kopczynska, M.; Haponiuk, J.; Piszczyk, Ł. Two-step conversion of crude glycerol generated by biodiesel production into biopolyols: Synthesis, structural and physical chemical characterization. J. Polym. Environ. 2018, 26, 3334-3344. [CrossRef]

35. Hejna, A.; Kosmela, P.; Olszewski, A.; Zedler, Ł.; Formela, K. Oil-assisted thermo-mechanical reclamation of ground tire rubber. In Scientific Collection "InterConf», (40), Proceedings of the 2nd International Scientific and Practical Conference «Scientific Community: Interdisciplinary Research», Hamburg, Germany, 26-28 January 2021; Busse Verlag GmbH: Hamburg, Germany, 2021 ; pp. 615-621.

36. Formela, K.; Klein, M.; Colom, X.; Saeb, M.R. Investigating the combined impact of plasticizer and shear force on the efficiency of low temperature reclaiming of ground tire rubber (GTR). Polym. Degrad. Stab. 2016, 125, 1-11. [CrossRef]

37. Gagol, M.; Boczkaj, G.; Haponiuk, J.; Formela, K. Investigation of volatile low molecular weight compounds formed during continuous reclaiming of ground tire rubber. Polym. Degrad. Stab. 2015, 119, 113-120. [CrossRef]

38. Członka, S.; Bertino, M.F.; Kośny, J.; Strąkowska, A.; Masłowski, M.; Strzelec, K. Linseed oil as a natural modifier of rigid polyurethane foams. Ind. Crop. Prod. 2018, 115, 40-51. [CrossRef]

39. Prociak, A.; Kurańska, M.; Malewska, E.; Szczepkowski, L.; Zieleniewska, M.; Ryszkowska, J.; Ficon, J.; Rzasa, A. Biobased polyurethane foams modified with natural fillers. Polimery 2015, 60, 592-599. [CrossRef]

40. Formela, K.; Hejna, A.; Zedler, Ł.; Przybysz, M.; Ryl, J.; Saeb, M.R.; Piszczyk, Ł. Structural, thermal and physico-mechanical properties of polyurethane/brewers' spent grain composite foams modified with ground tire rubber. Ind. Crop. Prod. 2017, 108, 844-852. [CrossRef]

41. Song, Z.-L.; Ma, L.-Q.; Wu, Z.-J.; He, D.-P. Effects of viscosity on cellular structure of foamed aluminum in foaming process. J. Mater. Sci. 2000, 35, 15-20. [CrossRef]

42. Zhang, X.; Tian, N.; Zhang, W.; Zhu, J.; Lu, C. Morphology, foaming rheology and physical properties of ethylene-propylene diene rubber/ground tyre rubber (GTR) composite foams: Effect of mechanochemical devulcanisation of GTR. Prog. Rubber Plast. Recycl. Technol. 2013, 29, 81-98. [CrossRef]

43. Formela, K.; Cysewska, M.; Haponiuk, J.; Stasiek, A. The influence of feed rate and shear forces on the devulcanization process of ground tire rubber (GTR) conducted in a co-rotating twin screw extruder. Polimery 2013, 58, 906-912. [CrossRef]

44. Formela, K.; Cysewska, M.; Haponiuk, J.; Stasiek, A. Effect of screw configuration and rotation speed of screws on quality of products of continuous thermomechanical devulcanization. Przem. Chem. 2012, 91, 2398-2402. 
45. Markl, E.; Lackner, M. Devulcanization Technologies for Recycling of Tire-Derived Rubber: A Review. Materials 2020, $13,1246$. [CrossRef]

46. Esteban, B.; Riba, J.-R.; Baquero, G.; Puig, R.; Rius, A.; Ruiz, J.-R.R. Characterization of the surface tension of vegetable oils to be used as fuel in diesel engines. Fuel 2012, 102, 231-238. [CrossRef]

47. Kurańska, M.; Banaś, J.; Polaczek, K.; Banaś, M.; Prociak, A.; Kuc, J.; Uram, K.; Lubera, T. Evaluation of application potential of used cooking oils in the synthesis of polyol compounds. J. Environ. Chem. Eng. 2019, 7, 103506. [CrossRef]

48. Ma, J.; Hu, M.; Sun, D.; Lu, T.; Sun, G.; Ling, S.; Xu, L. Understanding the role of waste cooking oil residue during the preparation of rubber asphalt. Resour. Conserv. Recycl. 2021, 167, 105235. [CrossRef]

49. Saiwari, S.; Dierkes, W.K.; Noordermeer, J.W.M. Devulcanization of Whole passenger car tire material. KGK Rubberpoint 2013, $66,20-25$.

50. Chuayjuljit, S.; Sangpakdee, T. Processing and properties of palm oil-based rigid polyurethane foam. J. Met. Mater. Miner. 2007, $17,17-23$.

51. Mosiewicki, M.; Dell'Arciprete, G.; Aranguren, M.; Marcovich, N. Polyurethane foams obtained from castor oil-based polyol and filled with wood flour. J. Compos. Mater. 2009, 43, 3057-3072. [CrossRef]

52. Nandi, S.; Winter, H.H. Swelling behavior of partially cross-linked polymers: A ternary system. Macromolecules 2005, 38, 4447-4455. [CrossRef]

53. Kosmela, P.; Hejna, A.; Suchorzewski, J.; Piszczyk, Ł.; Haponiuk, J.T. Study on the structure-property dependences of rigid pur-pir foams obtained from marine biomass-based biopolyol. Materials 2020, 13, 1257. [CrossRef]

54. Zedler, Ł.; Przybysz-Romatowska, M.; Haponiuk, J.; Wang, S.; Formela, K. Modification of ground tire rubber-Promising approach for development of green composites. J. Compos. Sci. 2019, 4, 2. [CrossRef]

55. Formela, K.; Cysewska, M.; Haponiuk, J. The influence of screw configuration and screw speed of co-rotating twin screw extruder on the properties of products obtained by thermomechanical reclaiming of ground tire rubber. Polimery 2014, 59, 170-177. [CrossRef]

56. Gibson, L.J.; Ashby, M.F. Cellular Solids: Structure and Properties, 2nd ed.; Cambridge University Press: Cambridge, UK, 2014. [CrossRef]

57. Usman, M.A.; Adeosun, S.O.; Osifeso, G.O. Optimum Calcium Carbonate Filler Concentration for Flexible Polyurethane Foam Composite. J. Miner. Mater. Charact. Eng. 2012, 11, 311-320. [CrossRef]

58. Chen, Y.; Das, R.; Battley, M. Effects of cell size and cell wall thickness variations on the strength of closed-cell foams. Int. J. Eng. Sci. 2017, 120, 220-240. [CrossRef]

59. Andersons, J.; Kirpluks, M.; Stiebra, L.; Cabulis, U. Anisotropy of the stiffness and strength of rigid low-density closed-cell polyisocyanurate foams. Mater. Des. 2016, 92, 836-845. [CrossRef]

60. Zhang, R.; Chen, J.; Zhu, Y.; Zhang, J.; Luo, G.; Cao, P.; Shen, Q.; Zhang, L. Correlation between the structure and compressive property of PMMA microcellular foams fabricated by supercritical $\mathrm{CO}_{2}$ foaming method. Polymers 2020, 12, 315. [CrossRef]

61. Boiko, Y.M.; Guérin, G.; Marikhin, V.A.; Prud'Homme, R.E. Healing of interfaces of amorphous and semi-crystalline poly(ethylene terephthalate) in the vicinity of the glass transition temperature. Polymers 2001, 42, 8695-8702. [CrossRef]

62. Boiko, Y.M.; Prud'Homme, R.E. Surface mobility and diffusion at interfaces of polystyrene in the vicinity of the glass transition. $J$. Polym. Sci. Part B Polym. Phys. 1998, 36, 567-572. [CrossRef]

63. Hatakeyama, H.; Hirogaki, A.; Matsumura, H.; Hatakeyama, T. Glass transition temperature of polyurethane foams derived from lignin by controlled reaction rate. J. Therm. Anal. Calorim. 2013, 114, 1075-1082. [CrossRef]

64. Gisbert, A.N.; Amorós, J.E.C.; Martínez, J.L.; Garcia, A.M. Study of Thermal Degradation Kinetics of Elastomeric Powder (Ground Tire Rubber). Polym. Technol. Eng. 2007, 47, 36-39. [CrossRef]

65. Laza, T.; Bereczky, Á. Basic fuel properties of rapeseed oil-higher alcohols blends. Fuel 2011, 90, 803-810. [CrossRef]

66. Ravey, M.; Pearce, E.M. Flexible polyurethane foam. I. Thermal decomposition of a polyether-based, water-blown commercial type of flexible polyurethane foam. J. Appl. Polym. Sci. 1997, 63, 47-74. [CrossRef] 